\title{
Distribution and Transport of Foliar Applied Zinc in Pistachio
}

\author{
Qinglong Zhang and Patrick H. Brown \\ Pomology Department, University of California, Davis, CA 95616
}

\begin{abstract}
ADDITIONAL INDEX wORDS. foliar uptake, stable isotope
Abstract. The distribution and transport of foliar applied $\mathrm{Zn}$ were determined for pistachio (Pistachio vera $\mathrm{L}$.) seedlings and mature trees using stable ${ }^{68} \mathrm{Zn}$ isotope. In seedlings, $\approx 5.4 \%$ of $\mathrm{Zn}$ adsorbed by the leaf was transported out of the treated leaves and this $\mathrm{Zn}$ was detected in all other plant parts to varying extent. In mature trees, the transport of $\mathrm{Zn}$ occurred both acropetally and basipetally within the leaflets with more basipetal movement; however, no significant amount of $\mathrm{Zn}$ was transported out of the treated leaflets during the first 10 days after application. The total percentage of $\mathrm{Zn}$ transported to other plant parts 20 days after application was significantly greater when $\mathrm{Zn}$ was applied to immature leaflets $(6.5 \%)$ than to mature leaflets $(2.1 \%)$, though the majority of the absorbed $\mathrm{Zn}$ remained within the treated leaflets. The limited mobility of foliar-absorbed $\mathrm{Zn}$ in pistachio may partially be attributed to the high binding capacity of leaf tissue for $\mathrm{Zn}$.
\end{abstract}

Foliar supply of nutrients is commonly practiced in fruit trees and vegetable crops, but its effectiveness is not consistent due to limited rates of leaf absorption and translocation. The initial absorption phase involves penetration through the cuticle and epidermal cells, while the subsequent transport of the foliar absorbed nutrients generally occurs via the phloem (Bidulph, 1954; Swanson and Whitney, 1953). The extent of redistribution of the applied nutrient is an important consideration in the use of foliar fertilization to satisfy the nutrient needs of plants. Foliar applied micronutrients generally exhibit a low mobility (Chamel, 1988; Ferrandon and Chamel, 1988) and Zn mobility varies with species (Bukovac and Wittwer, 1957; Loneragan et al., 1976). The effectiveness of foliar sprays of $\mathrm{Zn}$ varies greatly among species. Wallihan and HeymannHerschberg (1956) reported that $\mathrm{Zn}$ was readily absorbed by, and transported from, the leaves of citrus, while Wadsworth (1970) found only $0.2 \%$ of total applied $\mathrm{Zn}$ was absorbed and translocated out of the treated leaves of pecan. Although various treatments including chelating molecules have been used to improve the efficiency of foliar nutrient treatments (Alexander, 1986), the effectiveness of foliar sprays of $\mathrm{Zn}$ remains limited in many species.

The purpose of this study was to determine the distribution and the extent of transport of foliar absorbed Zn in 'Kerman' pistachio and to optimize $\mathrm{Zn}$ application techniques. Previous studies of foliar $\mathrm{Zn}$ uptake and translocation were conducted using radioactive ${ }^{65} \mathrm{Zn}$ as a tracer. In this study we demonstrate that the accuracy and precision of the measurements using inductively coupled plasmamass spectrometry (ICP-MS) make it possible to utilize stable isotope tracers of $\mathrm{Zn}$ in studies of foliar $\mathrm{Zn}$ uptake.

\section{Materials and Methods}

ZINC STABLE ISOTOPE PREPARATION. An enriched preparation of ${ }^{68} \mathrm{Zn}$ in the form of $\mathrm{Zn}$ oxide was obtained from Isotec Inc., Miamisburg, Ohio. The isotopic composition of this preparation was as follows (atom\%): ${ }^{64} \mathrm{Zn}, 2.95 ;{ }^{66} \mathrm{Zn}, 1.48 ;{ }^{67} \mathrm{Zn}, 0.73 ;{ }^{68} \mathrm{Zn}, 95.1$; ${ }^{70} \mathrm{Zn}, 0.22$. The natural isotopic composition of $\mathrm{Zn}$ is as follows (atom\%): ${ }^{64} \mathrm{Zn}, 48.89 ;{ }^{6} \mathrm{Zn}, 27.81 ;{ }^{67} \mathrm{Zn}, 4.11 ;{ }^{68} \mathrm{Zn}, 18.57 ;{ }^{70} \mathrm{Zn}, 0.62$. A known amount of the enriched preparation was dissolved in a few drops of $1 \mathrm{~N}$ acetic acid with shaking, followed by an equivalent

Received for publication 8 Sept. 1998. Accepted for publication 8 Mar. 1999. The cost of publishing this paper was defrayed in part by the payment of page charges. Under postal regulations, this paper therefore must be hereby marked advertisement solely to indicate this fact. volume of $0.1 \mathrm{~N} \mathrm{H}_{2} \mathrm{SO}_{4}$. The sample was heated at $75^{\circ} \mathrm{C}$ to near dryness and rediluted to the desired volume with double deionized (DDI) water. The $\mathrm{pH}$ of the solution was adjusted to 5.3 with $0.5 \mathrm{~N}$ $\mathrm{KOH}$.

Translocation AND Distribution OF FOLIAR ABSORBED ZINC IN PISTACHIO SEEDLINGS. Since previous reports on the transport of foliar-applied Zn were contradictory (Bukovac and Wittwer, 1957; Wadsworth, 1970; Wallinhan and Heymann-Herschberg, 1956), experiments were designed to test if the inconsistency is partly due to the effect of plant or leaf age.

Pistachio seeds were germinated and grown in medium grade vermiculite in shallow flats and fertilized with $1 / 4$ strength Hoagland's nutrient solution (Hoagland and Arnon, 1950) twice a week. Irrigation was provided as necessary. Seedlings were allowed to grow in the greenhouse until they had five to six leaves.

To study the distribution of $\mathrm{Zn}$ within the plant after foliar application, sixteen seedlings were chosen for uniformity. Two drops, each $40 \mu \mathrm{L}$ of $7.5 \mathrm{~mm}{ }^{68} \mathrm{Zn}$ solutions, were applied onto the adaxial surface of the third leaf from base. Treatment drops were applied to each side of the midvein in the mid section of the leaf. Treatments were replicated four times with 3 individual seedlings per replicate. At 2 and $10 \mathrm{~d}$ after application the plants were harvested and separated into treated leaves, leaves above and below the treated leaves, stems, and roots and prepared for $\mathrm{Zn}$ isotope analysis as described below.

Translocation AND DISTRIBUTION OF FOLIAR ABSORBED ZINC IN MATURE TREES. During May and June, the transport of foliar absorbed $\mathrm{Zn}$ was investigated by applying ${ }^{68} \mathrm{Zn}$ onto intact immature and mature leaflets of five individual trees grown in the pomology orchard at the University of California, Davis. One drop of $50 \mu \mathrm{L}$ ${ }^{68} \mathrm{Zn}$ solution $(7.5 \mathrm{~mm})$ was applied to the mid section of the leaflet on each side of the adaxial surface separated by the midvein. Treated leaflets (two leaflets per tree) were collected at 1,2,3, 5, 10, and 20 $\mathrm{d}$ after application and analyzed for the ${ }^{68} \mathrm{Zn}$. The transport of $\mathrm{Zn}$ from foliar application was estimated by the disappearance of ${ }^{68} \mathrm{Zn}$ from the treated leaflets, which was considered to have been transported to other plant parts.

Longitudinal transport of $\mathrm{Zn}$ within the leaflet under field conditions, was evaluated using leaflets treated as above. Leaf blades (five replications with two leaflets per replicate) were collected at 2, 7, and $25 \mathrm{~d}$ after application. Each leaflet was separated into three sections (apical, middle and basal). The ${ }^{68} \mathrm{Zn}$ in these three sections was analyzed to determine the localization of foliar absorbed $\mathrm{Zn}$. In another experiment, the lateral transport of foliar-absorbed $\mathrm{Zn}$ was 
investigated by applying two $50-\mu \mathrm{L}$ drops of ${ }^{68} \mathrm{Zn}$ to one side of the leaflet. Zinc isotope ratios in the leaflet were monitored in this side including the midvein, and on the opposite side $7 \mathrm{~d}$ after application.

Characteristics of ZINC BINDing to Leaf Cells. It is possible that the reported low translocation of $\mathrm{Zn}$ (Wadsworth, 1970) is due to fixation of $Z n$ to the leaf tissue. Hence, two additional experiments were conducted to examine the capacity of leaf cells to bind $\mathrm{Zn}$. A separate set of leaflets were collected from the mature trees treated with ${ }^{68} \mathrm{Zn}$ solution as described above. These leaflets were used to determine the proportion of soluble and insoluble ${ }^{68} \mathrm{Zn}$ in leaf tissue. At $40 \mathrm{~h}$ after application, leaflets were cut into small sections and ground in a mortar in $10 \mathrm{~mm}$ MES-NaOH buffer, $\mathrm{pH}$ 6.0, containing $0.35 \mathrm{~m}$ sorbitol; the ground samples were then divided into two equal aliquots and then homogenized by hand at $4{ }^{\circ} \mathrm{C}$, either with or without $0.5 \mathrm{~mm} \mathrm{CaSO}_{4}$. The homogenate was centrifuged at $500 \mathrm{~g}_{\mathrm{n}}$ for $10 \mathrm{~min}$, after which a loose pellet was formed. The pellet was filtered through a double layer of Miracloth (Calbiochem Corporation, La Jolla, Calif.). The residue was resuspended in $50 \mathrm{~mL}$ iced water and ultrasonicated (model 450; Branson Ultrasonics Corp., Danbury, Conn.) for $5 \mathrm{~min}$ at an output power of $40 \mathrm{~W}$. The homogenate was then centrifuged at $1000 g_{\mathrm{n}}$ for $10 \mathrm{~min}$ and refiltered through a double layer of Miracloth and washed with $50 \mathrm{~mL}$ of iced water twice. The filtered supernatant was collected and diluted to $250 \mathrm{~mL}$ (in $1 \%$ nitric acid) for $\mathrm{Zn}$ analysis (as water soluble $\mathrm{Zn}$ ). The residue was collected and dried at $70^{\circ} \mathrm{C}$, then ashed and analyzed as described below. Zinc still bound in this residue after the separation process was considered 'insoluble' $\mathrm{Zn}$. A separate set of leaflets without ${ }^{68} \mathrm{Zn}$ treatment were collected as the control and treated as described above.

Mechanical CELl isolation. The affinity for Zn of pistachio leaf tissue was investigated using leaf cells isolated mechanically according to the method of Grabber and Jung (1991), which involved a series of tissue grinding and filtration procedures. The isolated cells prepared in this way were determined microscopically to be viable mesophyll cells. Prepared cells were suspended in cold $0.35 \mathrm{M}$ sucrose, and were used within $1 \mathrm{~h}$ after final preparation. Dead cells were obtained by freezing and thawing these cells twice in liquid nitrogen.

About $10 \mathrm{~g}$ of cells (fresh weight) prepared in this way were placed in $100-\mathrm{mL}$ test vials with $25 \mathrm{~mL}$ of test solution $\left(100 \mu \mathrm{M}^{68} \mathrm{Zn}\right)$ for $6 \mathrm{~h}$. Cells were separated from the solution by centrifugation and filtration, cells were then washed with iced DDI water three times. The washed cells were collected, dry-ashed, and analyzed for ${ }^{68} \mathrm{Zn}$ (see below).

SAMPLE ANALYSIS. Leaf samples were washed with detergent (1\% Liquinox, Alconox, Inc., New York) and $0.1 \mathrm{~N} \mathrm{HCl}$, rinsed three times in DDI water, and dried at $70{ }^{\circ} \mathrm{C}$ for $72 \mathrm{~h}$. For all samples (leaves or isolated cells) ashing was performed overnight at $500^{\circ} \mathrm{C}$. Ash was then dissolved in $10 \mathrm{~mL} 1 \mathrm{NHNO}_{3}$ and heated to $110^{\circ} \mathrm{C}$ for $25 \mathrm{~min}$. After filtration, samples were made to $50 \mathrm{~mL}$ with DDI water.

A Perkin-Elmer (Norwalk, Conn.) SCIEX ELAN 500 ICP-MS system with a Meinhard nebulizer was used for all ion intensity measurements of $\mathrm{Zn}$ isotopes. Net intensity at 64, 66, 67, 68, and 70 mass units was monitored using total dwell time of $300 \mathrm{~ms}$ for isotopic ratio determinations. Ratios of ${ }^{68} \mathrm{Zn}$ intensity to the intensity of each of the other four isotopes ( $\mathrm{Zn} \mathrm{64,} \mathrm{66,} \mathrm{67,} \mathrm{and} \mathrm{70)} \mathrm{were}$ calculated, and the sensitivities of each ratio to ${ }^{68} \mathrm{Zn}$ enrichment were compared. The ${ }^{68} \mathrm{Zn} /{ }^{64} \mathrm{Zn}$ and ${ }^{68} \mathrm{Zn} /{ }^{66} \mathrm{Zn}$ ratio were each less sensitive to changes in ${ }^{68} \mathrm{Zn}$ enrichment in the sample than was the ${ }^{68} \mathrm{Zn} /{ }^{67} \mathrm{Zn}$ ratio. The ${ }^{68} \mathrm{Zn} /{ }^{70} \mathrm{Zn}$ ratio was oversensitive to changes in ${ }^{68} \mathrm{Zn}$ enrichment since the lower abundance of ${ }^{70} \mathrm{Zn}$ isotope resulted in highly variable intensity readings. Thus, the ratio of ${ }^{68} \mathrm{Zn} /{ }^{67} \mathrm{Zn}$ was chosen to calculate the ${ }^{68} \mathrm{Zn}$ enrichment in the sample. Net $\mathrm{Zn}$ absorption was calculated from the counts of each isotope for each sample without background correction. To correct the daily variations in the isotopic $\mathrm{Zn}$ ratios caused by changes in instrumental errors, the measured isotope ratio values were corrected by following the normalization procedure: the mean measured isotope ratio of the standard solution (every 10 samples), which was analyzed at intervals between samples during each instrument run, was divided by the natural abundance ratio (for ${ }^{68} \mathrm{Zn} /{ }^{67} \mathrm{Zn}, 4.5182$ ) to give a correction factor that was applied to the measured sample ratios obtained in that instrument run: $\mathrm{C}_{68: 67}=\mathrm{R}_{\text {experimental 68:67 }} / \mathrm{R}_{\text {Theoretical68:67 }}$.

The mass discrimination correction factors during a typical 8 hour period of operation ranged from 0.9855 to 1.0511 . National Institute of Standards and Technology (NIST) certified natural Zn standard samples (apple leaf) were measured periodically to check for drift in the $\mathrm{Zn}$ abundance ratio. The average coefficient of variation of duplicate isotope ratio determinations was $\approx 0.4 \%$ for nonenriched samples and $2.5 \%$ for enriched samples. The amount of ${ }^{68} \mathrm{Zn}$ derived from foliar treatment was calculated from the equation based on the isotope ratio modified from Ziegler et al. (1989): ${ }^{68} \mathrm{Zn}$ $=\left\{\mathrm{Zn}_{\mathrm{t}} \times 0.951 \times 0.0411\left(\mathrm{R}_{\mathrm{s} 68 / 67}-\mathrm{R}_{\mathrm{c} 68 / 67}\right)\right\} / 0.0073\left(\mathrm{R}_{\mathrm{e} 68 / 67}-\mathrm{R}_{\mathrm{s} 68 / 67}\right)+$ $\left.0.0411\left(R_{\mathrm{s} 68 / 67}-\mathrm{R}_{\mathrm{c} 68 / 67}\right)\right\}$, where $\mathrm{Zn}_{\mathrm{t}}$ is the total amount of $\mathrm{Zn}$ in $\mu$ moles in the sample, 0.0411 is the natural isotope abundance (fractional) of ${ }^{67} \mathrm{Zn}, 0.951$ is the abundance of ${ }^{68} \mathrm{Zn}$ in the enriched preparation. $\mathrm{Rs}_{68 / 67}$ and $\mathrm{Rc}_{68 / 67}$ are the determined isotope ratios of the treated leaf samples and untreated control samples, respectively. 0.0073 is the abundance of ${ }^{67} \mathrm{Zn}$ in the enriched preparation and $\mathrm{R}_{\mathrm{e} 68 /}$ ${ }_{67}(=129.58)$ is the $68 / 67$ isotope ratio of the enriched preparation.

The element Yttrium $\left(0.5 \mu \mathrm{g} \cdot \mathrm{mL}^{-1}\right)$ was added as an internal

Table 1. Distribution of ${ }^{68} \mathrm{Zn}$ among different plant organs following foliar application to intact leaves of 2-week-old pistachio seedlings

\begin{tabular}{lcc}
\hline \hline \multirow{2}{*}{ Zinc } & \multicolumn{2}{c}{ Days after application } \\
\cline { 2 - 3 } distribution $(\%)$ & 2 & 10 \\
\hline Total recovered & $12.5 \mathrm{a}^{\mathrm{z}}$ & $14.8 \mathrm{~b}$ \\
Treated leaf & $99.10 \mathrm{a}$ & $94.64 \mathrm{~b}$ \\
Stem & $0.33 \mathrm{a}$ & $2.68 \mathrm{~b}$ \\
Roots & $0.10 \mathrm{a}$ & $0.75 \mathrm{~b}$ \\
Leaves & & \\
$\quad$ & $0.12 \mathrm{a}$ & $1.13 \mathrm{~b}$ \\
$\quad$ Bbove treated leaf & $0.12 \mathrm{a}$ & $0.82 \mathrm{~b}$ \\
\hline
\end{tabular}

${ }^{\mathrm{z}}$ Means were compared between the 2 sampling days according to Fisher's protected LSD. Means with different letters differed significantly $(p<0.05)$. On a given day after application, only $\mathrm{Zn}$ distribution in the 'treated leaf' differed significantly from other organs.

yIncludes treated area.

Table 2. Distribution (\%) of recovered ${ }^{68} \mathrm{Zn}$ within the treated leaflet of intact mature pistachio trees

\begin{tabular}{lccr}
\hline \hline Leaf & \multicolumn{3}{c}{ Days after application } \\
\cline { 2 - 4 } section & 2 & 7 & \multicolumn{1}{c}{25} \\
\hline Total recovered & $18.8 \mathrm{a}^{\mathrm{z}}$ & $20.4 \mathrm{a}$ & $14.1 \mathrm{~b}$ \\
Mid section & $94.4 \mathrm{a}$ & $85.4 \mathrm{~b}$ & $82.4 \mathrm{c}$ \\
Apical section & $2.4 \mathrm{c}$ & $4.7 \mathrm{a}$ & $4.3 \mathrm{~b}$ \\
Basal section & $3.2 \mathrm{c}$ & $9.9 \mathrm{~b}$ & $13.2 \mathrm{a}$
\end{tabular}

${ }_{\mathrm{z}}$ Means were compared between the days after application according to Fisher's protected LSD. Means with different letters differed significantly $(p<0.05)$. On a given day after application, the $\mathrm{Zn}$ distribution in the midsection of the leaflet was significantly higher than that in the other two sections $(p<0.05)$.

yIncludes treated area. 


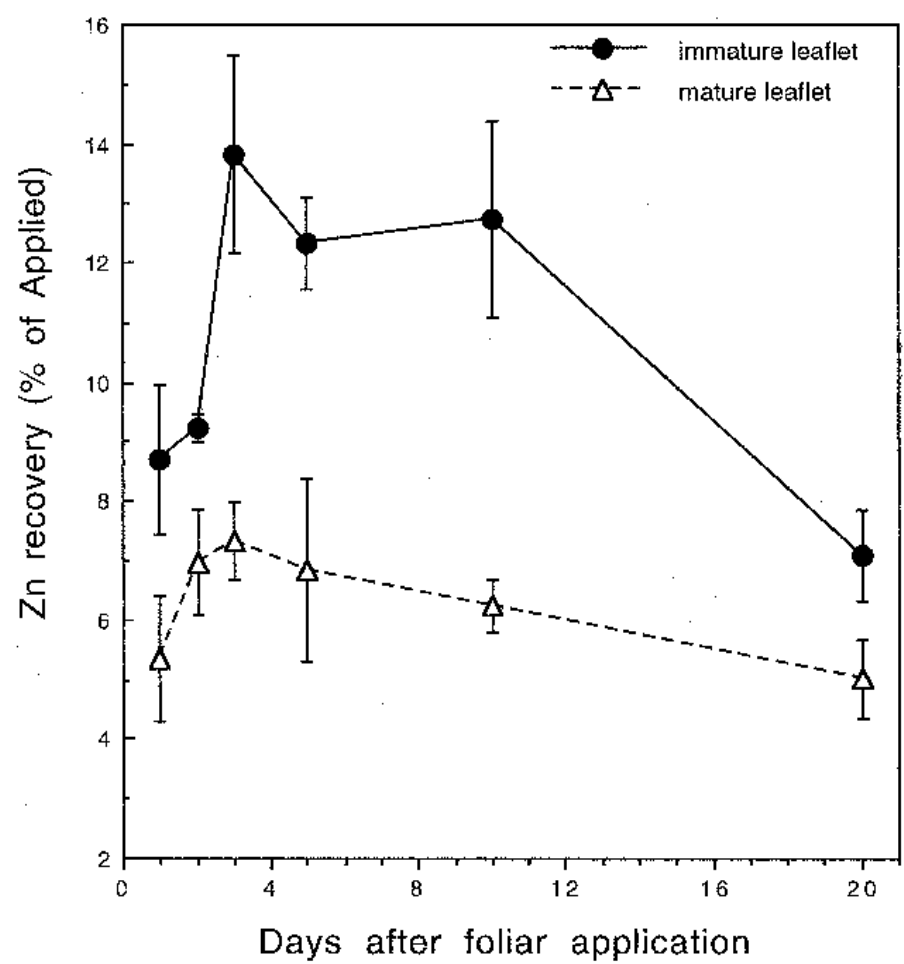

Fig. 1. Zinc recovery by pistachio leaflets after foliar ${ }^{68} \mathrm{Zn}$ application at the rate of $50 \mu \mathrm{g}{ }^{68} \mathrm{Zn}$ per leaflet. Each point is a mean of five replicates \pm sE.

standard using a two-inlet sample feeding system during the analysis. Recovery experiments to verify analytical accuracy were performed by spiking the leaf samples with known amounts of isotope before and after dry ashing. The results of isotope recovery, according to the above equation, ranged from $98.1 \%$ to $103.2 \%$ for samples spiked before dry ashing and $99.95 \%$ for samples spiked during wet extraction. This suggests that no $\mathrm{Zn}$ is lost during dry ashing or wet extraction procedures. The accuracy and precision of the ICP-MS measurements make it possible to quantify isotope tracers of $\mathrm{Zn}$ in biological samples where only a small percentage of the tracer is actually found.

Zinc recovery is defined as the ${ }^{68} \mathrm{Zn}$ remaining in the leaf following washing and is expressed as the percentage of total applied ${ }^{68} \mathrm{Zn}$. Preliminary studies with seedlings demonstrated that the percentage of ${ }^{68} \mathrm{Zn}$ that could be removed in the wash declined with time while ${ }^{68} \mathrm{Zn}$ recovered in plant tissues increased by an equivalent amount.

Statistical analysis. A completely randomized design was used for all experiments. Data were subjected to analysis of variance where appropriate. Fisher's protected LSD test was used for determining the significance of mean comparison.

\section{Results}

DISTRIBUTION AND TRANSPORT OF FOLIAR RECOVERED ZINC IN SEEDLINGS. Less than $1 \%$ of the foliar recovered $\mathrm{Zn}$ was transported outside the treated leaves $2 \mathrm{~d}$ after application (Table 1). Even $10 \mathrm{~d}$ after application, only $\approx 5.4 \%$ of the recovered $\mathrm{Zn}$ was transported out of the treated leaves, although ${ }^{68} \mathrm{Zn}$ was detected in all plant organs.

DISTRIBUTION AND TRANSPORT OF RECOVERED ZINC IN MATURE TREES. ${ }^{68}$ Zinc was found mostly in the midsection of the leaflet (where the ${ }^{68} \mathrm{Zn}$ was applied) even $25 \mathrm{~d}$ after application (Table 2). However, the distribution of $\mathrm{Zn}$ in the three sections changed significantly with time. $\mathrm{Zn}$ recovery in the midsection of the leaflet was $94.4 \%$ of the total recovery $2 \mathrm{~d}$ after application, and decreased to $82.4 \%$ at $25 \mathrm{~d}$. The change in $\mathrm{Zn}$ over the same time period was $>4$-fold in basal but <2-fold in apical, so it was likely that more was moving basipetally.

When $\mathrm{Zn}$ was applied to one side of the midvein, a significant $\mathrm{Zn}$ enrichment $\left({ }^{68} \mathrm{Zn} /{ }^{67} \mathrm{Zn}\right.$ ratio of 12.89$)$ was found only in this side of the leaflet, no isotopic enrichment was observed in the other side of the leaflet $\left({ }^{68} \mathrm{Zn} /{ }^{67} \mathrm{Zn}\right.$ ratio of 4.41 , which was not different from the control leaflet of 4.35). The results suggest that lateral movement of $\mathrm{Zn}$ across the midrib is very limited.

EFFECT OF LEAF AGE. Recovery of foliar-applied $\mathrm{Zn}$ in the treated leaflets increased with time and reached a maximum $\approx 3 \mathrm{~d}$ after application in both immature and mature leaflets (Fig. 1). The net reduction in $\mathrm{Zn}$ recovery, which was assumed to be due to net translocation of $\mathrm{Zn}$ out of the treated leaflets to other plant parts was estimated by the differences between day 3 and day 20. The amount of $\mathrm{Zn}$ recovered and transported from treated leaflets was significantly $(p<0.05)$ affected by leaf age. More of the applied ${ }^{68} \mathrm{Zn}$ was recovered in immature than mature leaflets. Immature pistachio leaflets transported a significantly greater amount of the recovered $\mathrm{Zn}(48 \%)$ than the mature leaflets $(28 \%)$ by $20 \mathrm{~d}$ after application.

Characteristics of ZinC Binding To Leaf CELls. The partitioning of $\mathrm{Zn}$ into soluble and insoluble fractions following foliar $\mathrm{Zn}$ application was determined by extraction in the presence or absence of $\mathrm{Ca}^{2+}$. When $\mathrm{Ca}^{2+}$ was not added to the tissue extraction solution, only $9.6 \%$ of the total recovered, foliar-applied ${ }^{68} \mathrm{Zn}$ was present as a soluble component while $90 \%$ remained in the insoluble form 40 $\mathrm{h}$ after foliar application (Table 3). This proportion of soluble Zn was significantly lower than found in control pistachio leaf tissue. When $\mathrm{Ca}^{2+}$ was added to the tissue extraction solution, soluble $\mathrm{Zn}$ in the leaf increased to $79 \%$ of the total $\mathrm{Zn}$ recovered.

In a separate experiment, the affinity for $\mathrm{Zn}$ of mechanically isolated leaf cells was determined by submerging living or dead leaf cells in a $100 \mu \mathrm{M}^{68} \mathrm{Zn}$ solution. The recovery of $\mathrm{Zn}$ from the treatment solution was more than $99 \%$ and $90 \%$ respectively, by living and dead cells. These results suggested high affinity for $\mathrm{Zn}$ in both living and dead cells.

\section{Discussion}

The mobility of foliar applied $\mathrm{Zn}$ varies greatly among species, ranging from only $0.2 \%$ of total applied $\mathrm{Zn}$ absorbed and translocated from the leaves in pecan (Wadsworth, 1970) to more than $80 \%$ in citrus and bean (Wallihan and Heymann-Herschberg, 1956; Bukovac and Wittwer, 1957). Our results demonstrated that 14 to $15 \%$ of the foliar applied $\mathrm{Zn}$ could be recovered 3 to $10 \mathrm{~d}$ after application. The absorption and transport of foliar-applied $\mathrm{Zn}$ from

Table 3. Forms of absorbed ${ }^{68} \mathrm{Zn}$ in mature pistachio leaf tissue $40 \mathrm{~h}$ after foliar application

\begin{tabular}{lcccr}
\hline \hline Zinc & $-{ }^{68} \mathrm{Zn}^{\mathrm{z}}$ & & \multicolumn{2}{c}{$+{ }^{68} \mathrm{Zn}$} \\
\cline { 2 - 5 } form & Control & & \multicolumn{2}{c}{ Extraction method } \\
\cline { 4 - 5 }$(\%)$ & $-\mathrm{Ca}^{2+}$ & & $-\mathrm{Ca}^{2+}$ & $+\mathrm{Ca}^{2+}$ \\
\hline Total recovery & --- & & $8.1 \mathrm{a}^{\mathrm{y}}$ & $7.2 \mathrm{~b}$ \\
Insoluble & $69.8 \mathrm{~b}$ & & $90.4 \mathrm{a}$ & $21.0 \mathrm{c}$ \\
Soluble & $30.2 \mathrm{~b}$ & & $9.6 \mathrm{c}$ & $79.0 \mathrm{a}$
\end{tabular}

${ }^{\mathrm{z} F o r m s}$ of $\mathrm{Zn}$ in the control sample were calculated based on total $\mathrm{Zn}$ content in the leaf.

'Means were compared among extraction methods according to Fisher's protected LSD. Means with different characters differed significantly $(p<$ $0.05)$. Extraction method significantly $(p<0.05)$ affected $Z n$ distribution in all cases. 
the treated area were much lower for mature than for immature leaflets. Mature leaflets translocated $\approx 2 \%$ of the applied $\mathrm{Zn}$, while immature leaflets translocated $\approx 6.5 \%$. Similar patterns of the absorption and translocation of foliar-applied $\mathrm{Zn}$ were observed in field trials (Brown et al., 1994).

The distribution of foliar applied $\mathrm{Zn}$ among different plant organs was not uniform, with a tendency for the majority of the $\mathrm{Zn}$ to be found in the stem $10 \mathrm{~d}$ after application. This differential transport of $\mathrm{Zn}$ absorbed by the leaf is consistent with the finding of Kannan and Keppel (1976) that ${ }^{65} \mathrm{Zn}$ accumulation was greatest in the stem subtending the Zn-treated leaf. However, our results are in contrast to the high translocation of ${ }^{65} \mathrm{Zn}$ to roots of dwarf bean (Pisum sativum) (Ferrandon and Chamel, 1988). These differences may be species-dependent. It should be noted that the results obtained from the seedlings may not apply to mature trees, in which the presence of developing nuts may serve as a major sink for nutrients (Brown et al., 1995).

The direction of $\mathrm{Zn}$ transport within the leaflet was investigated by separating the treated leaflet into apical, basal and middle sections. Zn was transported both acropetally and basipetally with greater basipetal transport. This is in contrast to the finding of Kannan and Keppel (1976) that Zn transport was only basipetal in corn leaves, regardless of the site of $Z n$ application on the leaf. The inconsistency may be attributed to the fact that different $\mathrm{Zn}$ concentrations were used and the nutrient movement may be concentration dependent. Using in vivo counting with $\beta$-sensitive semiconductor detectors, Ringoet et al. (1967) reported that foliar absorbed ${ }^{45} \mathrm{Ca}$ in oat leaves migrated acropetally at low concentration, but moved to the base of the leaf at concentrations above 20 mM.

Soluble $\mathrm{Zn}$ is most likely associated with the leaf symplast and is assumed to be available for transport to other plant parts. Only $9.6 \%$ of the total recovered, foliar-applied ${ }^{68} \mathrm{Zn}$ was present as a soluble component, while the majority of the newly absorbed $\mathrm{Zn}$ was insoluble. This may explain the limited mobility of $\mathrm{Zn}$ within the plants. Several investigators have suggested that $\mathrm{Ca}^{2+}$ must be present in the absorbing solution to maintain the integrity of the $\mathrm{Zn}$ absorbing mechanism (Bowen, 1969; Schmid et al., 1965). The rate of absorption rapidly declined in the absence of $\mathrm{Ca}^{2+}$ in excised roots and in leaf discs, while absorption continued at a constant rate for several hours when $\mathrm{Ca}^{2+}$ was added (Bowen, 1969; Schmid et al., 1965). In this study, when $\mathrm{Ca}^{2+}$ was added to the tissue extraction solution, a large portion of the insoluble $\mathrm{Zn}$ was released. Since tissues were extracted at low temperature (4 ${ }^{\circ} \mathrm{C}$ ), the effect of $\mathrm{Ca}^{2+}$ on active $\mathrm{Zn}$ absorption was likely negligible. This suggests that ion exchange occurs between the soluble and insoluble $\mathrm{Zn}$ in the leaves and that the presence of competing cations may be important in the overall effectiveness of $\mathrm{Zn}$ sprays.

Zinc applied to the solution bathing isolated cells was rapidly absorbed by those cells. Living cells removed essentially all $\mathrm{Zn}$ present in the solutions while dead cells removed $90 \%$. The difference in $\mathrm{Zn}$ recovery between living and dead cells suggests that $\approx 10 \%$ of the $\mathrm{Zn}$ was absorbed into the cytoplasm, and probably only this portion is available for further transport. The result corresponded to the $9.6 \%$ soluble $\mathrm{Zn}$ found in mature leaves following $\mathrm{Zn}$ application.

The results suggest that the slow movement and limited redistribution of foliar-applied $\mathrm{Zn}$ in mature leaflets is probably due to the low penetration of $\mathrm{Zn}$ into leaf tissue and the high affinity of tissues for $\mathrm{Zn}$. These two factors reduce the amount of $\mathrm{Zn}$ available for transport. Treatments that improve $\mathrm{Zn}$ penetration and reduce $\mathrm{Zn}$ complexation in cell walls might increase the effectiveness of $\mathrm{Zn}$ sprays.
Based on the distribution and transport of $\mathrm{Zn}$ determined here, we can make a rough estimate of how much a foliar $\mathrm{Zn}$ spray might increase tree $\mathrm{Zn}$ nutritional status. A field application rate of 2.24 $\mathrm{kg} \cdot \mathrm{ha}^{-1}$ of $\mathrm{ZnSO}_{4}(36 \% \mathrm{Zn})$ (currently recommended rate in California) will provide $\approx 4.32 \mathrm{~g}$ Zn per tree, assuming 187 trees/ ha $(7.3 \times 7.3 \mathrm{~m})$. An absorption and transport efficiency of $6 \%$ will provide $\approx 260 \mathrm{mg}$ elemental $\mathrm{Zn}$ per tree. This will increase average leaf $\mathrm{Zn}$ level by only $1.8 \mu \mathrm{g} \cdot \mathrm{g}^{-1}$ assuming an average mature tree size of $150 \mathrm{~kg}$ dry mass. This is consistent with the observed average increase of $2 \mu \mathrm{g} \cdot \mathrm{g}^{-1} \mathrm{Zn}$ following a single spring application in a three year field experiment in California orchards (Brown et al., 1994). This suggests that multiple sprays within a year, or sprays over several years, are needed to increase tree $\mathrm{Zn}$ status of pistachio by foliar application.

\section{Literature Cited}

Alexander, A. 1986. Crops need specific foliar application of micronutrients, p. 309-321. In: P. Morard (ed.). Proc. 2nd Intl. Symp. Role of Micronutrients in Agriculture, Cedipa, Toulouse.

Bidulph, O. 1954. The distribution of $\mathrm{P}, \mathrm{S}, \mathrm{Ca}$, and Fe in bean plants as revealed by use of radioactive isotopes, p. 7-17. In: Plant analysis and fertilizer problems, Intl. Congr Bot., 8th Congr., Paris, France.

Bowen, J.E. 1969. Absorption of copper, zinc, and manganese by sugarcane leaf tissue. Plant Physiol. 44:255-261.

Brown, P.H., Q. Zhang, and B. Beede. 1994. Effect of foliar fertilization on zinc nutritional status of pistachio trees. Annu. Rpt. Calif. Pistachio Ind., Crop Year 93-94:77-80.

Brown, P.H., S.A. Weinbaum, and G.A. Picchioni. 1995. Alternate bearing influences annual nutrient consumption and the total nutrient content of mature pistachio trees. Trees 9:158-164.

Bukovac, M.J. and S.H. Wittwer. 1957. Absorption and mobility of foliar applied nutrients. Plant Physiol. 32:428-434.

Chamel, A. 1988. Foliar uptake of chemical studies with whole plant and isolated cuticles, p. 27-50 In: P.M. Nuemann (ed.). Plant growth and leaf-applied chemicals. CRC Press, Boca Raton, Fla.

Ferrandon, M. and A.R. Chamel. 1988. Cuticular retention, foliar absorption and translocation of $\mathrm{Fe}, \mathrm{Mn}$ and $\mathrm{Zn}$ supplied in organic and inorganic form. J. Plant Nutr. 11:247-263.

Grabber, J.H. and G.A. Jung. 1991. Isolation of parenchyma and sclerenchyma cell types from the plant parts of grasses. Crop Sci. 31:838-842.

Hoagland D.R. and D.I. Arnon. 1950. The water-culture method for growing plants without soil. Univ. Calif. Agr. Expt. Sta. Circ. 347.

Kannan, S and H. Keppel. 1976. Differential migration of foliar applied zinc in maize plants. Z. Nuturforsch 31c:195.

Loneragan, J.F., K. Snowball, and A.D. Robson. 1976. Remobilization of nutrients and its significance in plant nutrition, p. 463-469. In: I.F. Wardlaw and J.F. Passioura (eds.). Transport and transfer processes in plants. Academic Press, New York.

Ringoet, A., R.V. Rechenmann, and H. Veen. 1967. Calcium movement in oat leaves measured by semi-conductor detectors. Radiat. Bot. 7:81-85.

Swanson, C.A. and J.B. Whitney, Jr. 1953. Studies on the translocation of foliar-applied $\mathrm{P}^{32}$ and other radioisotopes in bean plants. Amer. J. Bot. 40:816-823.

Schmid, W.E., H.P. Haag, and E. Epstein. 1965. Absorption of zinc by excised barley roots. Physiol. Plant. 18:860-869.

Wadsworth, G.L. 1970. Absorption and translocation of zinc in pecan trees MS thesis. Texas A\&M Univ., College Station.

Wallinhan, E.F. and L. Heymann-Herschberg. 1956. Some factors affecting absorption and translocation of zinc in citrus plants. Plant Physiol. 31:294-99.

Ziegler, E.E., R.E. Serfass, S.E. Nelson, R. Figueroa-Colon, B.B. Edwards, R.S. Houk, and J.J. Thompson. 1989. Effect of low zinc intake on absorption and excretion of zinc by infants studied with ${ }^{70} \mathrm{Zn}$ as extrinsic tag. J. Nutr. 119:1647-1653. 